\title{
On-farm management and quality assessment of farmers' saved wheat seed in the western Terai, Nepal
}

B Thapa Kshetri

Ministry of Agriculture and Cooperative, Nepal

\begin{abstract}
A study was conducted at Pakadi Village of Kapilbastu district, western Terai, Nepal in 2005 to find out the effect of on-farm seed management on the quality status of farmers' saved wheat seed. A survey was conducted to collect required information about on-farm seed management by using pre-tested questionnaires as well as to collect wheat seed samples, which were produced under general, additional and standard management practices. Survey showed that most of the farmers fulfilled their seed demand through informal sources. Roguing was not common practices in the study site and majority of the farmers saved seed from the harvest which was used for consumption purpose as well. Also, majority of farmers used to store unknown quality of seed in local containers by adopting simple storage techniques, which were one of the major causes of seed deterioration in their condition. Except physical purity, other seed quality attributes such as germination, 1000 seed weight and genetic purity percentage were found highest in certified seed. However, vital seed quality attribute viz. germination percentage of certified seed produced under standard management practice was statistically at par with seed produced under additional management practice. Likewise, other crop mixed seed, varietal mixing; and percentage infection of diseases such as Bipolaris sorokiniana and Alternaria spp. were found minimum in certified seed produced under standard management, while those attributes were recorded in high amount for seed produced under general and additional management followed by farmers. It showed that on-farm seed management played a significant role for maintaining seed quality parameters except physical purity and weed mixture in the seed. It was concluded that high quality wheat seed could be produced under farmers' condition by adopting additional management system with treatment and processing of seed.
\end{abstract}

Key Words: Certified seed, fumigation, genetic purity, roguing, seed quality, vigor

\section{Introduction}

Wheat is the third important cereal crop of Nepal after rice and maize both in area and production. At present, wheat-sown area is about 6,69,014 ha, with a total production of nearly 1.3 million ton (CBS, 2004). The productivity has steadily increased from 1.4 to 1.88 t/ha in the last ten years (NARC, 2002). However, average productivity of wheat is very low as compare to developed countries ( 7.7 ton/ha in U.K. and 6.5 ton/ha in France) Joshi and Regmi (1988). Even though wheat is third important crop of Nepal, it is second important for Kapilbhastu district. It is cultivated in 27000 hectares and average productivity is 2.5 ton/ha (DADO, Kapilbastu, 2004). There are several technical constraints associated with low productivity of wheat in Nepal. Poor crop stand due to low quality seed is one of the major causes of low productivity wheat in Nepal (Mudbari et al., 1998).

Quality seed is considered as the basic, critical and cheapest input for enhancing productivity (Rana, 1997). Seed is not only input but also dynamic instrument for increasing agriculture production (Jha and Rai, 2001). Use of quality seed can increase crop yield up to 15-25\% (DISSPRO, 1999). Use of other inputs such as fertilizer, irrigation, plant protection, does not yield good economic return without use of quality seed (Thapa, 2005). Seed quality is judged by its genetic purity, vigour and germination, 
analytical (physical) purity, freedom from seed borne diseases and higher yielding ability (Rana and Raut, 1997). Thus, Seed is biological basis of the world food security and, directly or indirectly supports the livelihood of every person on earth.

A large number of Nepalese farmers are storing wheat seed in rainy season in ambient condition, when there is high temperature and high rainfall which accelerate quality degradation of stored seed in such condition. Due to high temperature and high rainfall, most of the farmers are sowing poor quality seed, which may be one of the main causes of low productivity of wheat in Nepal (Thapa, 2005). For instances, a survey conducted by SDQCSS (now SQCC) identified germination quality status of farmers' saved wheat seed which showed that only $36 \%$ samples were within standard, whereas $64 \%$ samples were below standard (Shrestha and Mishra, 2001).

National Seed Company (NSC) is responsible for supplying cereal seed to the farmers. It is supplying only 3-5\% cereal seed out of total seed requirement of the country. Not only that seed supplied by NSC is very nominal it does not fulfill the demand of the farmers, it is expensive, cannot be available in time and these are not suitable varieties as demanded by the growers. Therefore, farmers do not want to depend upon this institution for seed supply and they prefer to save the seed by themselves or exchange among farmers to farmers (Bhandari, 2002). In Nepal, formal seed sale account for only a small percentage of the actual requirement, being less than $2 \%$ incase of rice, $12 \%$ for wheat and $1 \%$ for maize (SSSP, 2003). In totality almost $90 \%$ of the seed requirement of major crops and $100 \%$ of minor crops is met by farmers' own seed production and supply system (Cromwell et al., 1993; Joshi, 1995; Baniya et al., 2000 as cited by Sthapit and Sah, 2001). Thus importance of the informal extension and supply system (farmer-to-farmer networks) is verygeneral practice in Nepal because the formal extension and seed supply system are weak (Green, 1997 cited by Sthapit and Sah, 2001).

Up to now, government, donor agencies, NGO/INGO and other institutions are focusing formal seed sector that only supply $10 \%$ of the total seed requirement of the country though seed produced by farmers is the most important seed source in the majority of developing countries (Almekinders, 2000). Hence, agricultural productivity can be increased up to $20 \%$ by maintaining the quality of farmers' seed. Farmers' seed system is not getting priority and support and very rarely included in research even though it plays significant role in food security and livelihood of the poor people. Although national seed policies and plans are in the line to encourage the private sectors in seed business, but the cereal crops are high volumes, low price commodities. So private sectors are reluctant to get involved in the cereal seed business because it is risky, needs heavy physical facilities and infrastructures and less profitable as compare to vegetables (Bhandari, 2002).

For this purpose, Crop Development Directorate (CDD)a plan was prepared "District Level Seed Self Sufficiency Program (then DISSPRO) by creating source center. Major focus was given on rice, maize and wheat seed multiplication program in farmers' group of selected districts to supply source seed and improved seed for commercial cultivation (Bhandari, 2002). But DISSPRO program is not running as per its manual (Shrestha and Mishra, 2001).

Hence, survey and quality assessment of farmers' seed are key component to assess the causes of quality deterioration of farmers' mnaged seed. It is therefore; necessary to study the on-farm seed management and quality assessment of farmers' saved wheat seed to maintain the quality of seed for increasing agriculture production through focusing informal seed system (farmers' seed system) at Pakadi village of Kapilbastu district. 


\section{Methodology}

\section{Method and techniques of data and sample collection}

In order to cover wheat-growing area in the survey, two wards out of 9 , were selected from lottery system in collaboration with respective service center of DADO. Name and number of households (Voter list) were obtained from respective VDCs office in Taulihawa. Selected households, where ther wer not real owner had been omitted from the list with the help of key informants and substitute farmers were selected for interview. Thus, it was necessary to select 26 and 22 farmers in ward number 3 and 4 , respectively for interviewing 12 farmers in each ward to meet minimum requirement of minimum sampling i.e. $15 \%$ of real population. Out of 48 randomly selected households, study and sampling were undertaken with only 24 households by using standard pre-designed and pre-tested questionnaires. During survey, 24 wheat seed samples were collected from farmers and 6 samples of certified seed lots were also collected from National Seed Company, Bhairahawa with by following seed sampling procedures of International Seed Testing Association (ISTA) Rules, 2006.

\section{Farmers under general management}

With field survey data, farmers who adopted some common agricultural practices related to seed quality such as seed drying, seed cleaning, cleaning of seed storage, maintenance of seed storage, use of local containers (gunny bag, dehari etc.), keeping seed lot aside the wall, use of wooden plank, brick stand or any material as pallet, and time to time inspection of seed store to check the insect infestation were considered as general management.

\section{Farmers under additional management and standard management}

Including general managements, farmers who are adopting special or extra agricultural practices for seed quality such as use of separate plot for seed production, roguing of the field, use of vapor proof containers, use of local herbs and insecticide in seed and seed storage respectively, use new containers for seed storage or fumigation of old containers during seed storage. They were categorized under additional management. Six samples of certified seed produced by contract farmers of National Seed Company Bhairahawa by following strict rules of seed technology were categorized under standard management (such as use of verified seed source, use of recommended packages of practices for cultivation, adoption of proper roguing, field certification, harvesting and threshing inspection, storage inspection, pre-cleaning of seed in processing plant, complete seed test before storage, use of insecticide in seed storage, use of new container or fumigation of old container during seed storage, time to time fumigation of seed lots to control insect infestation, quality test during seed storage, seed treatment and processing, and bagging and tagging of seed (in plastic laminated gunny bags at safe moisture level)

\section{Treatment details}

Each farmer (i.e. sample) was taken as a replication and 3 types of managements of seed production under farmers' conditions were considered as 3 treatments. According to field survey data, 10 farmers (i.e. 10 replications) were adopting the general management practices (T1), 14 farmers (i.e. 14 replications) were adopting the additional management (T2), 6 certified seed samples of National Seed Company, Bhairahawa (6 replications) were produced under standard management practices (T3). 


\section{Seed Testing}

For the lab experiment, Completely Randomized Design (CRD) with unequal replications was used. All seed samples were tested for parameters such as number of seeds, physical purity, germination, seed health, 1000 seed weight and phenol color test for varietal purity which were carried out in collaboration with Central Seed Testing Laboratory, Hariharbhawan, Lalitpur, Nepal. All samples were sealed in thick polythene bag and stored in deep freeze at $-5^{0} \mathrm{C}$ to avoid the change in quality of seed until tests were performed.

\section{Data analysis}

First of all, information collected from the field survey was coded, tabulated and analyzed by using Statistical Package of Social Science (SPSS). Simple descriptive statistics was used to separate the mean and standard deviation to describe the socio-economic characteristics of the respondents.

\section{Result and discussion}

\section{Surveyed information on seed source, mode of receiving seed, quality, and seed replacement}

Only $20.8 \%$ farmers of research site used seed completely obtained from formal sources and rest of the farmers met their demand of wheat seed from informal sources. Of the total farmers, about $(91 \%$ purchased wheat seed for sowing. It showed that buying was popular means of receiving the seed in Pakadi village. Remaining percentage of farmers used seed grown from their own crop. More than 80 percent of farmers of research site tested seed before sowing. However, they did not send the samples in seed testing laboratory for testing (Annex 1). It was encouraging that majority of the farmers were aware of seed quality and all farmers replaced the seed with in 1-3 years after the first use (Annex 2). However, they were testing seed by themselves. So, it necessary to provide the seed testing training to enrich their knowledge for seed testing and seed evaluation.

\section{On-farm seed management}

It was found that majority of farmers (i.e. 95.8\%) cleaned seed immediately after harvesting but few farmers also reported that they did not clean seed after harvesting. Most of the farmers of research site were (i.e. $75 \%$ ) saving seed from total harvest and only one fourth of the farmers (25\%) used separate plot for seed production. Around one third of farmers (29.2\%) removed off type plants but they did not remove other weed plants such as Vicia spp., Chenopodium album, Rumex spp. etc. and other crop plants except canary grass and oat respectively. All farmers of the village (100\%) dried the seed before and during storage but some farmers were drying the seed only for 2-3 hours, which was not sufficient to reduce the seed moisture at safe level for storage. Roguing was not common practice of the research site and majority of the farmers separate seed from total harvest (Annex 3).

\section{On-farm seed management for seed saving and storage}

All farmers of research site were storing seed without seed testing. Majority of farmers (79.1\%) used the earthen dehari (Bhakari) for seed storage. One third of the farmers (i.e.33.3\%) used the local materials such as neem leaves, onion bulb and wheat husk as local herbs for controlling the insect infestation during storage to protect the viability of the seed. Most of the farmers were adopting the simple storage management practices such as cleaning of store (100\%), maintenance of seed store and use of pallet 
(90.9\% of farmers in each), keeping seed lot aside the wall (73.7\%) and inspection for fumigation to control insect and pests $(86.4 \%)$. In case of pallet, all farmers were using the brick stand below the dehari to protect the seed from moisture of earthen floor. Only very few farmers followed the other important storage management techniques such as use of insecticide before storage and use of new containers or fumigation of old containers before use respectively. It showed that majority of the farmers were storing unknown quality seed in local containers with simple storage techniques. It was one of the major causes of seed deterioration in farmers' condition (Annex 4).

\section{Laboratory findings}

\section{Purity}

Purity percentage of seed produced by farmers under different managements was statistically at par with each other $(\mathrm{P}<0.05)$ which significant and superior to certification standards. The purity percentages were $98.68,98.98$ and 98.90 for seeds produced by farmers under general, additional and standard management, respectively. The highest purity percentage (98.98) was found for seed produced under additional management because farmers had small seed lot as compared to certified seed production management. Hence, farmers could maintain the seed properly with using local materials (Annex 5). It showed that high percentage of analytically pure seed could be produced under farmers' management condition.

\section{Germination}

The highest germination percentage viz. 88.36 was found in certified seed produced under standard management but it was statistically at par with farmers' seed produced under additional management $(83.79 \%)$. It was fond that if farmers could adopt additional management practices properly, seed with good germination capacity as in certified seed production system under standard management could be produced by themselves under their condition (Annex 5).

\section{Seed quality determination by other tests}

Number of other crop seed (OCS) and other distinguishable variety (ODV) were significantly lower in certified seed than that of seed produced by farmers under generaland additional management condition. In certified seed production, farmers removed the off-types and all other crop plants during roguing due to compulsion of seed certification. Farmers also adopt rouging practice under additional management but it was not as enough as in certified seed. So, it is necessary to suggest to farmers to adopt proper rouging practice in additional management as in certified seed production for maintaining the physical and genetic purity of seed.

Farmers did not care to other weed plants except objectionable weeds such as Convolvulus arvensis (which is not found in Nepal) in wheat field in certified seed production. They only removed the Phalaris minor from field during roguing in additional management. However, in general management, farmers did not adopt roguing practices. So, number of weed seed present in seed produced under different managements was statistically at par with each each other. (Annex 6). Seed was pre-cleaned and cleaned during processing of certified seed but farmers had very small seed lot as compared to certified seed, so they might have cleaned it properly by using local materials. Due to this reasons, number of weed seed present in farmers' seed was lower than that of certified seed. 


\section{Thousand seed weight}

Thousand seed weight of certified seed produced under standard management $(42.40 \mathrm{~g})$ was significantly higher than that of seed produced by farmers' under general $(36.02 \mathrm{~g})$ and additional management (37.06 g) at 5\% level of significance. Certified seed was produced by adopting improved package of practices with verified seed source. In addition to this, immature and shriveled seed were also removed during processing to make the seed lot uniform, which had also positive effect on 1000 seed weight of certified seed (Annex 7).

\section{Seed health test}

The infection percentage of Bipolaris sorokiniana and Alternaria spp. in certified seed (i.e.0.35 and $1.48 \%$ ) was found very low as compared to seeds produced by farmers under general (17.68 and 33.08\%) and additional management (15.53 and 32.31\%) respectively at $5 \%$ level level of significance. It was due to the fact that certified seed was treated with vitavax during seed processing time but farmers' produced seed was untreated. So the infection percentage of Bipolaris sorokiniana and Alternaria spp. was low in certified seed than that of farmers' produced seed under general and additional management (Annex 8).

\section{Phenol color test for varietal purity}

Varietal purity of farmers' produced seed under general (88.27\%) and additional (90.02\%) management was statistically lower than that of certified seed $(97.75 \%)$ seed produced under standard management at $5 \%$ level of significance. Contract farmers involved in certified seed production removed the all off type plants properly during roguing. In additional management, farmers also adopt rouging practice as well but it showed that they did not rogue the off type plants properly as in standard management. However, farmers did not adopt roguing practice under general management (Annex 9).

\section{Conclusion}

Majority of the farmers fulfilled their seed demand through informal sources. Even though farmers were aware of seed quality. They were sowing low quality seed after increasing seed rate due to inability to afford quality seed. Roguing was not common practices at research site and most of farmers saved seed from harvest which was generally used as consumption purpose. Farmers were storing unknown quality of seed in local containers by adopting simple storage techniques, which were one of the major causes of seed deterioration in on-farm condition. On-farm seed management played a significant role on maintaining seed quality parameters except seed purity and number of weed mixed in the seed. It could be concluded that high quality wheat seed could be produced under farmers' condition by adopting additional management system with treatment and processing of seed. It is also necessary to organize the Seed Quality Management training and DISSPRO program effectively in farmers' condition for strengthening farmers' seed system in Nepal.

\section{Reference}

Almekinders, C. 2000. The importance of informal seed sector and its relation with the Legislative framework. Website information.

Bhandari, D. 2002. Crop Development Program and Achievements in the Ninth Five-Year Plan. His Majesty's Government, Ministry of Agriculture and Co-operatives, Department of Agriculture, Crop Development Directorate, Hariharbhawan, Lalitpur, Nepal. p55.

Central Bureau of Statistics (CBS). 2004. His Majesty's Government, National Planning Commission Secretariat, Central Bureau of Statistics. 
DADO (District Agriculture Development Office). 2004. Annual Agricultural Development Program and Statistical book. HMG/N, MOAC, DOA, District Agriculture Development Office, Taulihawa, Kapilbastu, Nepal. $78 \mathrm{p}$.

District Level Seed Self Sufficiency Programme (DISSPRO): A Guideline. 1999. His Majesty's Government, Ministry of Agriculture and Co-operatives, DOA, Crop Development Division, Hariharbhawan, Lalitpur. $19 \mathrm{p}$.

Jha, N and A Rai. 2001. Approaches of AIC on ensuring cereal seed supplies. Proceeding of third National Seed Seminar, August 13-14, Kathmandu, Nepal. pp.139-151.

Joshi, M and KR Regmi. 1988. Trainer's Manual Wheat. MOA, DOA, Manpower Development Agriculture Project, Kathmandu. 290p.

Mudbari, A, MR Bhatta, and DR Pokhrel. 1997. Increasing wheat production in Nepal. In: S. Nagarjan, G Singh, BSTyagi (eds.) Wheat Research Needs Beyond 2000 A.D. Proceeding of International Group meeting on "Wheat Research Needs Beyond 2000 A.D." held at Directorate of Wheat Research, Karnal, India, during 12-14, Narosa publishing house, New Delhi, Madras, Bombay, Calcutta, London. 396p.

(NARC) Nepal Agricultural Research Council, Khumaltar. 2002. NARC, Annual Report 2001/2002, Khumaltar, Lalitpur, Nepal.

Rana, DS. 1997. Guidelines for Seed Quality Control and Minimum Seed Certification Standards. HMG/FAO, Improvement of Seed Quality Control Services Project (TCP/NEP/6611). Food and Agriculture Organization of the United Nation. 136p.

Rana, DS and RK Raut. 1997. Quality control standards for cereals vegetables and other important agricultural crops. In R.K.Raut (ed.) Proceedings of the National Workshop on seed quality control, November 24-25, 1997, Kathmandu, Nepal. pp. 7-34.

Shrestha, HK, and RK Mishra. 2001. Present seed quality status of food grains and management for its promotion. In: Workshop on Review of Crop Development Program During Ninth Five Year Plan and Strategy for Tenth Five Year Plan, proceedings of National Workshop compiled and edited by DR Bhandari, 8-9 October 2001, Kathmandu, Nepal. pp. 23-32.

Seed Sector Support Project, Technical Report No.29. 2003. Project Support on Cereal Seed Development HMG/N, MOAC, Department of International Development, UK. 30p.

Sthapit, B, RP Sah. 2001. Strengthening crop research and farmer seed system. In Proceeding of third National Seed Seminar, August 13-14, Kathmandu, Nepal. pp.32-46.

Thapa, B. 2005. Vigour test methods and Accelerated ageing test. A term paper presented in Institute of Agriculture and Animal Science (IAAS), Rampur, Chitawan. Retrieved August 23, 2005

http://www.sls.wau.nl/tad/staff/ConnyAlmekinders/GTZ_July5.pdf. 
Annex 1. Categorization of farmers on the basis of different sources of wheat seed used at Pakadi VDC, Kapilbastu in 2005

\begin{tabular}{|c|c|c|}
\hline \multirow[t]{2}{*}{ Use of seed sources } & \multicolumn{2}{|c|}{ Farmers (Farmers saving wheat seeds for sowing) } \\
\hline & No. & $\%$ \\
\hline Formal & 5 & 20.8 \\
\hline Informal & 9 & 37.5 \\
\hline Both & 10 & 41.7 \\
\hline Total & 24 & 100 \\
\hline Completely own source & 2 & 8.3 \\
\hline Own as well as external source & 9 & 37.5 \\
\hline Completely external source & 13 & 54.2 \\
\hline Total & 24 & 100 \\
\hline \multicolumn{3}{|l|}{ Mode of receiving seed } \\
\hline Buying & 20 & 91.0 \\
\hline Barter & 1 & 4.5 \\
\hline Other (as a minikit from farm) & 1 & 4.5 \\
\hline Total & 22 & 100 \\
\hline \multicolumn{3}{|c|}{$\begin{array}{l}\text { Query for germination (if seed from external } \\
\text { sources) }\end{array}$} \\
\hline Yes & 18 & 81.8 \\
\hline No & 4 & 18.2 \\
\hline Total & 22 & 100 \\
\hline \multicolumn{3}{|c|}{ Seed testing before sowing (if self source) } \\
\hline Yes & 9 & 81.8 \\
\hline No & 2 & 18.2 \\
\hline Total & 11 & 100 \\
\hline Self seed testing & 9 & 100 \\
\hline
\end{tabular}

Annex 2. Categorization of farmers according to wheat seed replacement at Pakadi VDC, Kapilbastu in 2005

\begin{tabular}{lcc}
\hline Seed replacement period & \multicolumn{2}{c}{ No. and percentage of farmers } \\
& No. & \% \\
\hline One year & 2 & 58.3 \\
Two years & 14 & 33.3 \\
Three years & 8 & $\mathbf{1 0 0}$ \\
Total & $\mathbf{2 4}$ & 4.2 \\
Reason for Seed replacement & 1 & 95.8 \\
Due to poor genetic make up of self save seed & 23 & $\mathbf{1 0 0}$ \\
Due to good yielding ability of new seed. & $\mathbf{2 4}$ & \\
Total & & \\
\hline
\end{tabular}


Annex 3. Categorization of farmers according to on-farm wheat seed management practices at Pakadi VDC, Kapilbastu in 2005

\begin{tabular}{lcc}
\hline Seed management practicess & No. and percentage of farmers (N=24) \\
No. & \% \\
\hline Seed Cleaning & 23 & 95.8 \\
Yes & 1 & 4.2 \\
No & 24 & 100 \\
Total & 24 & 100 \\
Seed drying in sun & & 25 \\
Seed selection procedures & 6 & 75 \\
Use of separate seed production plot & 18 & 100 \\
Use of seed from total harvest & 24 & 29.2 \\
Total & & 66.7 \\
Rouging of the field & 7 & 4.2 \\
Yes & 16 & 100 \\
No & 1 & \\
Don't know & 24 & 70 \\
Total & & 20 \\
Post harvest seed drying & & 10 \\
Before storage (times) & 14 & 100 \\
One time & 4 & 61.9 \\
Two times & 2 & 33.3 \\
Three times & 20 & 4.8 \\
Total & & 100 \\
Ofter storage (times) & 13 & 7 \\
Two times & 1 & \\
Three times & 21 & \\
Total & & \\
\hline
\end{tabular}

Annex 4. Percentage category of farmers on the basis of different practices of wheat seed storage followed at Pakadi VDC, Kapilbastu in 2005

\begin{tabular}{lcc}
\hline Activity & $\begin{array}{c}\text { Percentage category of farmers } \\
\text { (N=24) }\end{array}$ & \% \\
\hline Seed saving for next season & No. & 100 \\
Storage without seed testing & 24 & 100 \\
Use of Storage containers & 24 & 79.1 \\
Earthen dehari & & 12.5 \\
Gunny bag & 19 & 4.2 \\
Gunny bag with plastic lamination & 3 & 4.2 \\
Dehari and gunny bag & 1 & $\mathbf{1 0 0}$ \\
Total & 1 & $33.3(66.6)$ \\
Use of local herbs & $\mathbf{2 4}$ & 100 \\
Cleaning of seed store before seed storage & $8(16)$ & $8.3(91.7)$ \\
Use of insecticide before storage & 24 & $90.9(9.1)$ \\
Maintenance of seed storage & $2(22)$ & $17(94.4)$ \\
Fumigation of old container & $20(2)$ & $90.9(9.1)$ \\
Use of pallet & $1(5.6)$ & $73.7(26.3)$ \\
Keeping seed lot aside the wall & $20(2)$ & $86.4(13.7)$ \\
Inspection for fumigation to control insect and pests & $14(5)$ & $19(3)$ \\
\hline
\end{tabular}

- Figure in parentheses indicate percetage of farmers who don't follow activity given 
Annex 5. Seed purity and germination as affected by different seedmanagement practiceson on farmers' saved wheat seed at Pakadi VDC, Kapilbastu in 2005

\begin{tabular}{clcc}
\hline Seed management practice & Purity & Germination \\
\hline 1. & General management & $98.68(9.934) \mathrm{a}$ & $67.05(54.97) \mathrm{b}$ \\
2. Additional management & $98.98(9.949) \mathrm{a}$ & $83.79(66.26) \mathrm{a}$ \\
3. & Standard management & $98.90(9.945) \mathrm{a}$ & $88.36(70.05) \mathrm{a}$ \\
SEM & 0.01195 & 2.720 \\
LSD $(\mathrm{P}<0.05)$ & 0.03468 & 7.894 \\
\hline
\end{tabular}

- Figures in parentheses are arcsine transformed means

- Means in the column followed by same letter are not significantly different at 5\% level by DMRT

Annex 6. Seed quality parameter as affected by different seed management practices of wheat on farmers' saved wheat seed at Pakadi VDC of Kapilbastu district in 2005

\begin{tabular}{cllll}
\hline \multicolumn{2}{c}{ Seed management practice } & $\begin{array}{c}\text { No. of other crop } \\
\text { seed (OCS) }\end{array}$ & $\begin{array}{c}\text { No. of other } \\
\text { distinguishable } \\
\text { variety (ODV) }\end{array}$ & No. of weed seed \\
\hline 1. & General management & $91.62(1.962) \mathrm{a}$ & $44.46(1.648) \mathrm{a}$ & $39.90(1.601) \mathrm{a}$ \\
2. & Additional management & $89.54(1.952) \mathrm{a}$ & $30.13(1.479) \mathrm{a}$ & $40.64(1.609) \mathrm{a}$ \\
3. & Standard management & $7.60(0.881) \mathrm{b}$ & $7.10(0.851) \mathrm{b}$ & $55.72(1.746) \mathrm{a}$ \\
\hline & & & \\
\hline SEM & 0.09335 & 0.0676 & 0.05477 \\
LSD $(\mathrm{P}<0.05)$ & 0.2709 & 0.1962 & \\
\hline
\end{tabular}

- Means in the column followed by same letter are not significantly different at the 5\% level by DMRT

- $\quad$ Figures in parentheses are log transformed means

Annex 7. 1000 seed weight as affected by different management practices on farmers' saved wheat seed at Pakadi VDC, Kapilbastu in 2005

\begin{tabular}{llc}
\hline Seed management practice & $\mathbf{1 0 0 0}$ seed weight mean $(\mathbf{g})$ \\
\hline 1. & General management & $36.02 \mathrm{~b}$ \\
2. & Additional management & $37.06 \mathrm{~b}$ \\
3. & Standard management & $42.40 \mathrm{a}$ \\
& SEM & 0.8942 \\
LSD $(\mathrm{P}<0.05)$ & 2.595 \\
\hline
\end{tabular}

- Means in the column followed by same letter are not significantly different at 5\% level by DMRT 
Annex 8. Seed health as affected by different treatments on farmers' saved wheat seed at Pakadi VDC, Kapilbastu in 2005

\begin{tabular}{|c|c|c|}
\hline Seed management practice & Bipolaris sorokiniana & Alternaria spp. \\
\hline 1. General management & $17.68(4.264) \mathrm{a}$ & $33.08(35.11) \mathrm{a}$ \\
\hline 2. Additional management & $15.53(4.004) \mathrm{a}$ & $32.31(34.64) \mathrm{a}$ \\
\hline 3. Standard management & $0.355(0.925) b$ & $1.48(6.98) b$ \\
\hline SEM & 0.1498 & 1.516 \\
\hline LSD $(\mathrm{P}<0.05)$ & 0.4345 & 4.398 \\
\hline
\end{tabular}

- Means in the column followed by same letter are not significantly different at $5 \%$ level by DMRT

- Figure in parentheses are transformed means (square root for Bipolaris sorokiniana and arcsine Alternaria spp.)

Annex 9. Phenol color test as affected by different seed management practices on farmers' saved wheat seed at Pakadi VDC, Kapilbastu in 2005

\begin{tabular}{lc}
\multicolumn{2}{c}{ at Pakadi VDC, Kapilbastu in $\mathbf{2 0 0 5}$} \\
\multicolumn{1}{c}{ Seed management practice } & Phenol color test mean \\
\hline General management & $88.27(9.395) \mathrm{b}$ \\
Additional management & $90.02(9.488) \mathrm{b}$ \\
Standard management & $97.75(9.887) \mathrm{a}$ \\
& \\
SEM & 0.03485 \\
LSD $(\mathrm{P}<0.05)$ & 0.1011 \\
\hline
\end{tabular}

- Means in the column followed by same letter are not significantly different at 5\% level by DMRT

- The figures in parentheses are square root transformed means 